Síntese - Rev. de Filosofia

v. 35 N. 111 (2008): 57-86

\title{
SOBRE A FILOSOFIA MORAL DE ADAM SMITH*
}

\author{
Hugo E. A. da Gama Cerqueira**
}

Resumo: Este artigo discute a Teoria dos sentimentos morais de Adam Smith. $\mathrm{O}$ argumento central do texto é apresentado, tomando por base o contexto proporcionado pela filosofia moral do Iluminismo escocês. Os conceitos de simpatia e espectador imparcial são discutidos, apontando-se a maneira original como Smith concebe a relação entre a moralidade e a sociabilidade.

Palavras-chave: Adam Smith, simpatia, espectador imparcial, newtonianismo moral, Iluminismo escocês.

Abstract: This article examines Adam Smith's Theory of moral sentiments. The moral philosophy of the Scottish enlightenment is central to the argumentation developed in this paper which analyses the concepts of "sympathy" and of "impartial spectator" and points to the originality of Smith's argument regarding the relationship between morality and sociality.

Key words: Adam Smith, sympathy, impartial spectator, moral Newtonianism, Scottish enlightenment.

\footnotetext{
* Trabalho realizado com o apoio do Consel ho Nacional de Desenvolvimento Científico e Tecnológico (CNPq) e do Programa de Auxílio à Pesquisa de Doutores Recém-Contratados (PRPq/UFMG). As referências aos textos de Smith seguem a notação consagrada pela Edição Glasgow de sua obra.

** Professor do Cedeplar, Universidade Federal de Minas Gerais. Artigo submetido a avaliação no dia 16/08/2006 e aprovado para publicação no dia 23/03/2007.
} 
$s$ últimos trinta anos assistiram o surgimento de um renovado interesse pelo pensamento de Adam Smith entre estudiosos de diferentes disciplinas. As comemorações do bicentenário da Riqueza das nações, em 1976, podem ser tomadas sem muita arbitrariedade como o marco inicial deste movimento de releitura que ganhou corpo na forma de um número crescente de artigos e livros sobre sua obra e, ao mesmo tempo, numa crítica severa às maneiras convencionais de interpretá-la.

Do ponto de vista que nos anima, dois aspectos merecem ser destacados quanto à natureza das tentativas recentes de compreender o pensamento de Smith. Em primeiro lugar, os novos intérpretes têm buscado tratar as diferentes partes de sua obra como elementos de um todo integrado. Partese do reconhecimento de uma estreita conexão entre os argumentos da Teoria dos sentimentos morais e da Riqueza das nações, o que vem contribuindo para colocar em novas bases a velha discussão sobre a relação entre a filosofia moral e a economia política de Smith e, ao mesmo tempo, revelar as limitações daquelas interpretações de seu pensamento econômico centradas exclusivamente na leitura da Riqueza das nações (Cerqueira, 2005). Em segundo lugar, tem havido um esforço de localizar a obra de Smith em relação aos problemas e motivações intelectuais do século XVIII, de situar seu pensamento em relação aos movimentos intelectuais de sua época e, mais particularmente, em relação ao lluminismo escocês (CERQUEIRA, 2006).

A pesar disso, não há qualquer exagero em afirmar que a Teoria dos sentimentos morais segue sendo pouco lida e conhecida: ainda que ela possa ser listada entre os grandes tratados de ética, sua estrutura e argumento estão longe de terem sido plenamente analisados. Se é fato que houve algum empenho em comparar a filosofia moral de Smith às concepções de autores como Hume, Kant e A ristóteles, não é menos certo que resta muito a fazer para compreender seus víncul os e diferenças com as abordagens de outros autores (GRISWOLD Jr, 1999: 25).

Nesta direção, o objetivo básico deste ensaio é explicitar o argumento central da filosofia moral de Smith à luz dos contexto proporcionado pelo Iluminismo escocês. O argumento é desenvolvido em cinco seções, além desta introdução e de al gumas notas conclusivas. As duas primeiras seções apresentam as questões que orientaram a formulação da filosofia moral do Iluminismo escocês - particularmente as de Francis Hutcheson e de David Hume. Nelas discute-se a apropriação do método newtoniano pelos escoceses e contrapõem-se suas concepções àquelas de duas tradições que lhes eram rivais: o racionalismo e o egoísmo moral. As seções seguintes apresentam a filosofia moral de Smith, discutindo que medida ele adere à visão providencialista que Ihe é geralmente imputada e analisando os conceitoschave da Teoria dos sentimentos morais - a simpatia e o espectador imparcial - para apontar a originalidade da concepção smithiana da relação entre a moralidade e a sociabilidade. 


\section{O newtonianismo moral do Iluminismo escocês}

George Turnbull (1698-1748) parece ter sido o primeiro entre os moralistas escoceses a advogar por escrito que o método newtoniano, seguido com tanto êxito na filosofia natural, também deveria ser adotado nas pesquisas sobre temas morais. Em duas teses redigidas em 1723 e 1726, ${ }^{1}$ durante o período em que foi regent no $M$ arischal College, ele afirmou haver uma conexão íntima entre a filosofia natural e a filosofia moral, julgando que a primeira consistiria no fundamento seguro para esta última (WOOD, 2000; 2003).

Como se sabe, a sugestão sobre este tipo de conexão remonta à obra do próprio Newton, que na questão 31 de sua Ó ptica, afirmava:

“E se a filosofia natural em todas as suas partes vier, enfim, a ser aperfeiçoada através da adoção deste método, os limites da filosofia moral também serão alargados. Pois, assim como podemos saber pela filosofia natural qual é a causa primeira, que poder ele exerce sobre nós e que benefícios recebemos dele, do mesmo modo nosso dever para com ele, bem como para com nossos semelhantes, nos será revelado pela luz da natureza." (NEWTON, 2004: 381).

Turnbull não apenas cita esta passagem, como insiste em afirmar que coube à filosofia natural demonstrar a existência do Criador e seu domínio providencial sobre a natureza, obra projetada de maneira sábia e benevolente. Tal concepção era partilhada por outros newtonianos na primeira metade do século XVIII, como Colin Maclaurin (1698-1746), o maior matemático e físico escocês do século XVIII. Colega de Turnbull no M arischal College e um dos grandes divulgadores da obra de Newton, Maclaurin afirmou em seu Relato sobre as descobertas filosóficas de Sir Isaac $\mathrm{N}$ ewton, que

“a filosofia natural é útil a propósitos de um tipo mais elevado e deve ser apreciada principalmente por lançar um fundamento seguro para a religião natural e a filosofia moral, por nos levar de uma maneira agradável ao conhecimento do Autor e Governante do universo. Estudar a natureza é pesquisar sua obra; toda nova descoberta revela-nos uma nova parte do seu plano" (MACLAURIN, 1997: 782).

Em obras posteriores, como as O bservações sobre a educação liberal, Turnbull retomaria o tema da conexão entre as filosofias natural e moral, afirmando que elas formavam um campo único do conhecimento humano e proporia um mapa das ciências destinado a mostrar aos jovens a verdadeira unidade do conhecimento:

"Com efeito, eu encontrei na prática um mapa geral das ciências - mostrando-as brotar do mesmo tronco e raiz, e uma da outra, e intimamente

\footnotetext{
${ }^{1}$ Respectivamente, De scientiae naturalis cum philosophia morali conjunctione e De pulcherrima mundi cum materialis tum rationalis constitutione.

${ }^{2}$ A primeira edição da Optica data de 1804 e continha 16 questões. A questão que hoje em dia conhecemos como a de número 31 surgiu pela primeira vez na edição latina de 1806, com o número de 23.
} 
conectadas entre si - de grande uso para abrir as mentes dos jovens, para inflamar sua curiosidade e seu desejo de conhecimento e, sobretudo, para manter para sempre sob seus ol hos a verdadeira unidade de todas as ciências, quaisquer que sejam as diferentes classes ou categorias em que sejam divididas. E é fácil conceber como tal árvore pode ser delineada, pois da experiência natural ou conhecimento das leis do mundo material, brotam imediata e naturalmente todas as artes mecânicas, e da experiência moral, de maneira igualmente imediata e natural, brotam todas as artes morais, entre as quais as mais notáveis são a política, a oratória e a poesia, e todas estas têm, evidentemente, uma dependência e conexão recíprocas muito estritas." (TURNBULL, 2003: 390-391).

Em outra parte da mesma obra, ele afirmaria que uma teoria moral deve se basear no estudo empírico dos poderes da mente humana, numa "revisão completa e acurada dos vários princípios naturais ou poderes naturais e disposições da humanidade, no modo como eles se dispõem em relação uns ao outros e aos objetos circundantes" (TURNBULL, 2003: 384).

Estas referências às obras de Turnbull e Maclaurin ajudam a compreender e a colocar no devido contexto os desenvolvimentos posteriores, empreendidos por Smith, Hume, Reid e outros, que se inspiraram de maneira ostensiva no modelo newtoniano para estabelecer seus próprios métodos de investigação. ${ }^{3} \mathrm{~N}$ este sentido, as observações feitas por Hume na introdução ao Tratado da natureza humana sobre as relações entre a ciência do homem e as demais ciências, bem como sua crença na aplicabilidade do método experimental ou indutivo à filosofia moral aparecem como uma preocupação amplamente compartilhada por aqueles que o antecederam na cena escocesa (WOOD, 2003: 107; 2000: 130-133). ${ }^{4}$

A o empreenderem suas investigações morais, a questão que mais ocupava os iluministas escoceses consistia exatamente em saber como é possível conhecer o modo moralmente correto de agir. Smith, por exemplo, julgava que, ao discutir os princípios de ética, haveria duas questões que deveriam ser consideradas:

“Em primeiro lugar, em que consiste a virtude? Ou qual é o tipo de temperamento e de padrão de conduta que constituem o caráter excelente e louvável, aquele caráter que é objeto natural de estima, honra e aprovação? E, em segundo lugar, por qual poder ou faculdade do espírito esse caráter,

\footnotetext{
${ }^{3}$ Ver DOMINGUES (1991: 165ss.) para uma discussão, de um ponto de vista não restrito ao Iluminismo escocês, das tentativas empreendidas ao longo do século XVIII no sentido de estender a perspectiva newtoniana aos domínios que viriam a conformar as ciências humanas.

4 "Assim como a ciência do homem é o único fundamento sólido para as outras ciências, assim também o único fundamento sólido que podemos dar a ela deve estar na experiência e na observação. Não é de espantar que a aplicação da filosofia experimental às questões morais tenha tido que esperar todo um século desde a sua aplicação à ciência da natureza" (HUME, 2001: 22). Ressalte-se, entretanto, que para Hume, ao contrário de Turnbull, a ciência humana é que deve servir de fundamento para a filosofia natural.
} 
seja ele qual for, nos é recomendado? Ou, em outras palavras, como e por quais meios sucede que o espírito prefira um padrão de conduta a outro, que denomine um de correto e o outro de errado, que considere um como objeto de aprovação, honra e recompensa, e o outro de reprovação, censura e punição?" (TM S VII.i.2)

Como bons empiristas que eram, os literati julgavam que uma resposta adequada à segunda questão só poderia ser obtida a partir das evidências proporcionadas pela experiência. Neste sentido, eles rejeitavam de modo enfático a solução proposta pelos racionalistas, como ficaram conhecidos aqueles que afirmavam que os juízos morais seriam obtidos através da razão, entre os quais Ralph Cudworth (1617-1688), Samuel Clarke (1675-1729), William Wolaston (1659-1724) e John Balguy (1686-1748). Para estes autores, a razão seria capaz de recorrer a critérios imutáveis para distinguir o bem e o mal ou para discernir que ações são em si mesmas corretas, virtuosas, justas etc., da mesma maneira como é capaz de reconhecer uma prova matemática ou a existência de propriedades geométricas (BEAUCHAMP, 2003: 19).

O combate aos racionalistas ocupou um espaço privilegiado nos escritos de Hume e Smith. O primeiro, ao abordar a questão da origem das distinções morais logo no início do terceiro livro do Tratado, asseverou que a razão é por si só impotente para despertar paixões ou produzir ações. $\mathrm{Na}$ medida em que a moral influencia as paixões e ações humanas, despertando afetos e produzindo (ou impedindo) ações, Hume argumenta que as regras da moral não podem ser apenas conclusões de nossa razão (2001: 497; 1978: 457). ${ }^{5}$ Smith, por sua vez, mesmo concedendo que a razão participa da formulação das regras gerais da moralidade, na medida em que as obtemos pela indução de situações particulares que agradam ou desagradam às nossas faculdades morais, é bastante claro ao afirmar que as percepções primárias sobre o certo e o errado em cada situação específica nos são dadas pelo sentimento imediato, e não pela razão (TM S VII.iii.2).

É preciso, no entanto, notar que as diferenças entre racionalistas e empiristas quanto à maneira como concebiam a origem de nossos preceitos morais não impediram que estes autores concordassem em torno de outros pontos importantes. Em primeiro lugar, el es estavam de acordo que a moralidade e a teologia, apesar de relacionadas, deveriam ser distinguidas. Para os racionalistas a obrigação de agir conforme a razão era superior ao dever de agir conforme a vontade divina, na medida em que esta última também deveria se submeter a uma lei original. Neste sentido, as referências à vontade de Deus, tal como expressas nas escrituras, seriam insuficientes para determinar os deveres morais dos homens, conclusão que também era sustentada pelos empiristas e que colocava a ambos em oposição direta

\footnotetext{
${ }^{5}$ A mesma posição é reiterada, em linhas gerais, na Investigação sobre os princípios da moral [An inquiry concerning the principles of morals].
} 
aos defensores do calvinismo ortodoxo, que concediam preeminência à orientação provida pela palavra de Deus e registrada nas escrituras (BERRY, 1997: 157).

Em segundo lugar, a simples rejeição do argumento racionalista sobre a origem de nossas idéias sobre o bem e o mal não foi impedimento para que as opiniões dos empiristas e racionalistas convergissem em relação a aspectos importantes de suas teorias morais e de sua compreensão sobre a natureza da virtude e da moralidade. Postulando que a aprovação ou desaprovação moral não poderiam provir da razão, o empirismo dos escoceses não era suficiente para estabelecer a natureza da conduta virtuosa. Ao consultarem a experiência em busca de uma resposta a esta questão, eles se viram freqüentemente em acordo com os racional istas sobre o conteúdo da nossa moralidade cotidiana, na medida em que ambos se colocaram em oposi ção aos adeptos do "egoísmo moral", afirmando a capacidade da natureza humana de experimentar o sentimento da benevolência e de julgar de maneira imparcial e desinteressada (BEAUCHAMP, 2003: 19).

\title{
Os escoceses e o egoismo moral
}

De fato, a filosofia moral proposta pel os escoceses pode ser entendida, em larga medida, como uma resposta ao desafio colocado por autores como Thomas Hobbes (1588-1679) e Bernard Mandeville (1670-1733). O primeiro, concebendo a natureza humana como dotada de apetites e aversões, afirmara que o objeto do apetite ou desejo de um homem é o que

\begin{abstract}
"ele, por sua parte chama de bom; e o objeto de seu ódio e aversão é o que chama de mal; e ao de seu desprezo, chama de vil e indigno. Pois estas palavras bom, mau e desprezível são sempre usadas em relação a pessoa que as emprega, não havendo nada que o seja simples e absolutamente, nem qualquer regra comum do bom e do mal que possa ser tirada da própria natureza dos objetos" (HOBBES, 1996: 39).
\end{abstract}

Sendo o bem e o mal assim definidos, e considerando que o estado de natureza consiste numa condição de guerra de todos contra todos - um estado em que todo homem tem direito a todas as coisas, até mesmo ao corpo dos demais (Hobbes, 1996: 91) -, Hobbes conclui a necessidade de que os homens transfiram ao Estado o direito de governar, atribuindo a ele a prerrogativa de estabelecer as regras que definem o bem e o mal e de usar da força e de outros recursos para impô-las e vêlas respeitadas. Neste sentido, a filosofia de Hobbes foi entendida como reduzindo o conteúdo da moralidade a obediência à vontade do soberano. ${ }^{6}$ Reações a esta doutrina

${ }^{6}$ Que é como Smith interpreta as idéias de Hobbes. De acordo com elas, "as meras idéias de louvável e censurável devem ser idênticas àquelas de obediência e desobediência. As 
não tardaram a surgir, sendo as críticas ora formuladas por autores da matriz racionalista, já mencionada, ora por pensadores que, como Shaftesbury, teriam particular importância para a formulação da filosofia moral dos literati.

De acordo com este último, Hobbes estaria errado ao propor que os homens fossem natural e exclusivamente voltados para a busca de seus próprios interesses, reduzindo, desta maneira, toda motivação moral ao amorpróprio. Sem chegar ao extremo oposto de afirmar que os homens seriam por natureza virtuosos, Shaftesbury propôs a existência de um sentido moral próprio à natureza humana que permitiria a qualquer um distinguir o bem do mal. Esta capacidade funcionaria de modo análogo à maneira como percebemos espontaneamente a beleza de um objeto: a exemplo do sentido do belo, o sentido moral permitiria apreciar a beleza moral presente nas relações humanas (SH AFTESBURY, 2001: 172-5, 182ss.; BERRY, 1997: 157-8; BEAUCHAMP, 2003: 19).

Coube a Mandeville formular, do ponto de vista do egoísmo moral, a resposta mais contundente à filosofia de Shaftesbury. A exemplo de H obbes, mas adotando um tom muito mais provocativo, ele argumentou que os homens não são naturalmente sociáveis ou benevolentes, mas que a motivação básica das ações humanas é a busca do interesse pessoal. Para ele, cada homem "é um composto de várias paixões", e "todas elas, na medida em que são provocadas e tornam-se predominantes, governam-no por seu turno, quer ele queira ou não" (Mandeville, 1988: 39). Sendo o homem naturalmente inclinado a buscar sua própria satisfação sem considerar os interesses dos demais, o estabelecimento da sociedade fica, então, na dependência de que, de um lado, o governo exerça o controle sobre os homens através da força e, de outro, que os homens sejam civilizados, isto é, convencidos eles mesmos a subjugar seus apetites, deixando de lado seu interesse privado para se preocupar com o interesse público. Esta última condição, reconhece Mandeville, dificilmente seria atingida se os homens não fossem compensados de al gum modo por esta renúncia a suas inclinações naturais. Por este motivo, os legisladores

“... examinaram minuciosamente todas as forças e fragilidades de nossa natureza, e notando que nenhuma era tão primitiva que não pudesse ser cativada com o louvor, ou tão vil que pudesse tolerar pacientemente a desonra, concluíram, com razão, que a lisonja deve ser o argumento mais poderoso que pode ser empregado com as criaturas humanas." (MANDEVILLE, 1988: 42-43).

Deste modo, os legisladores organizaram a sociedade de tal maneira a recompensar o orgulho e vaidade daqueles que promovessem o bem público, punindo os demais com a vergonha. O homem selvagem foi, assim,

leis do magistrado civil, por conseguinte, devem ser consideradas os únicos critérios definitivos do que é justo e injusto, do que é certo e errado" (TMS VII.iii.2.1). 
civilizado e aprendeu a chamar de vício tudo aquilo que o homem persegue para satisfazer seus próprios apetites, sem considerar o bem público, e de virtude as ações pelas quais o homem contraria os impulsos da natureza para tornar-se bom:

“É visível, portanto, que não foi qualquer religião pagã ou outra superstição idólatra que, pela primeira vez, instigou o homem a contrariar seus apetites e a subjugar suas mais caras inclinações, mas sim o governo habilidoso de políticos prudentes. E quanto mais intimamente buscarmos na natureza humana, mais nos convenceremos de que as virtudes morais são a prole política que a lisonja gerou no orgulho" (MANDEVILLE, 1988: 51).

Por esta via, Mandeville vê no conjunto das ações que resultam das paixões e desejos humanos uma expressão do amor-próprio. Isto vale, até mesmo, quando estamos nos referindo a "boas ações". N este caso, ou bem agimos por uma motivação que é diretamente egoísta - como quando damos esmolas a um pedinte para aliviar nossa compaixão ou simplesmente para podermos seguir adiante em nosso caminho sem sermos incomodados - ou bem agimos de uma maneira que apenas aparentemente sacrifica nosso próprio interesse, quando na verdade somos secretamente movidos pelo orgulho e, nesta medida, buscamos satisfazer uma paixão que é também egoísta (KAYE, 1988: 62-63).

Não surpreende, portanto, que Mandeville fizesse menção repetidas vezes à diferença entre o que os homens efetivamente fazem (buscar seu interesse pessoal) e aquilo que dizem fazer (sacrificar seu interesse pessoal pelo do público). ${ }^{7}$ É possível argumentar que, ao propor esta comparação, sua intenção não fosse a de acusar de hipócritas os homens que consideram agir de modo virtuoso. Para Mandeville, os homens simplesmente se deixam enganar sobre suas reais motivações (KAYE, 1988: 63). Não obstante, aos olhos dos leitores de sua época, os textos de Mandeville foram entendidos como contendo uma clara denúncia daquela hipocrisia e, neste sentido, exigiam uma refutação sistemática. Tanto mais porque ele não hesitou em afirmar que a filosofia de Shaftesbury, apesar de generosa e refinada, era falsa e inconsistente com nossa experiên cia cotidiana (Mandeville, 1988: 324; BERRY, 1997: 158).

Dentre os que se opuseram à defesa do egoísmo por Mandeville, interessanos mais de perto a resposta oferecida por Francis Hutcheson. A poiandose simultaneamente na filosofia moral de Shaftesbury e na epistemologia de Locke, Hutcheson concebeu a existência de sentidos internos - por analogia aos sentidos externos da visão, do olfato etc. - que seriam responsáveis por produzir as idéias simples de beleza e de bem moral. De acordo com ele, é com base em um dos sentidos internos que formulamos nossos juízos e distinções morais, percebendo as qualidades morais dos indivídu-

${ }^{7}$ Cf., entre outras passagens, Mandeville (1988: 166). 
os e de suas ações, à semelhança da maneira como, segundo Locke, os sentidos externos permitem que o homem perceba as qualidades secundárias dos objetos externos. Definindo um sentido como "uma determinação da mente, independente da nossa vontade, para receber qualquer idéia da presença de um objeto que se encontra diante de nós", Hutcheson concebe o sentido moral (moral sense) como o poder de receber percepções de uma ação moral, percepções distintas daquelas que derivam da mera vantagem que podemos obter da ação (Hutcheson, 2004: 90). A um só tempo, ele nega que o bem moral possa ser reduzido ao bem natural (ao interesse ou vantagem natural) e estabelece que o prazer extraído de um objeto através dos sentidos é anterior a qual quer consideração racional sobre o interesse ou vantagem que dele podemos extrair (TURCO, 2003: 136-137).

De acordo com Hutcheson, a idéia de um bem natural ou felicidade nos é dada inicialmente pelo prazer que extraímos em nossas percepções sensíveis de qualquer tipo. Este prazer dá origem ao desejo de possuirmos aqueles objetos que o provocam (ou de possuir objetos que nos permitem obtêlos, como as riquezas) e nossa inclinação natural para buscá-lo é o que chamamos de amor-próprio ou interesse pessoal. ${ }^{8}$ Por outro lado, a idéia de bem moral deriva dos prazeres que extraímos ao perceber a presença da benevolência em um agente, o seu desejo de promover a felicidade dos outros:

“... tão logo uma ação qualquer nos é representada como resultando do amor, da humanidade, da gratidão, da compaixão, de um zelo pelo bem dos outros e um deleite por seu prazer, ainda que seja na mais remota parte do mundo ou em alguma época passada, nós sentimos alegria em nosso íntimo, admiramos a ação graciosa e louvamos seu autor" (HUTCHESON, 2004: 91).

Neste sentido, explica Hutcheson, a moralidade não se confunde com a busca do interesse pessoal; o bem moral é distinto do bem ou vantagem natural. A benevolência provoca em nós uma estima pela pessoa em quem a observamos, ao passo que o bem natural dá origem apenas a um desejo de posse pelo objeto que desperta o prazer. A diferença entre estas percepções é, para Hutcheson, um fato da natureza humana de que qualquer um pode se convencer ao refletir sobre as distintas maneiras como é afetado pelo bem moral e pelo bem natural. Se não fosse assim, deveríamos ter para com seres inanimados os mesmos sentimentos e afecções que temos para com seres racionais, o que, afirma, sabemos não ser verdade: nossos sentimentos em relação a um terreno fértil ou a uma habitação espaçosa não são os mesmos que sentimos por um amigo generoso ou alguém de índole nobre. Ou ainda - para tomarmos mais um dos exemplos de que Hutcheson se vale para demonstrar seu ponto -, se obtemos a mesma vantagem de dois homens diferentes, dos quais o primeiro nos serve por

\footnotetext{
${ }^{8}$ Hutcheson ressalta que "o nosso sentido de prazer é prévio à vantagem ou interesse e é o seu fundamento. Não percebemos prazer nos objetos porque é de nosso interesse fazêlo, mas os objetos ou ações são vantajosos e são perseguidos ou empreendidos pelo interesse porque deles recebemos prazer" (Hutcheson, 2004: 86).
} 
boa vontade e pelo prazer que sente em nossa felicidade, ao passo que o segundo age por interesse pessoal ou coerção, nutriremos sentimentos diversos em relação a eles, apesar de serem igualmente vantajosos para nós (HUTCHESON, 2004: 89-90; Berry, 1997: 159). E o que permite que percebamos esta diferença, que tenhamos uma percepção da ação moral distinta da que decorre da mera vantagem é exatamente o fato de dispormos de um senso moral: "uma determinação de nossas mentes para receber idéias agradáveis ou desagradáveis de ações quando elas se encontram sob nossa observação, [determinação] prévia a quaisquer opiniões sobre a vantagem ou a perda que redundam, para nós, destas ações" (HUTCHESON, 2004: 100).

Se deixarmos em segundo plano a obra de outros autores da primeira metade do século XVIII, é razoável apontar a filosofia moral de Hume como o capítulo seguinte desta controvérsia secular sobre a fundamentação da moralidade. ${ }^{9}$ Os aspectos mais importantes das posições por ele adotadas podem ser encontrados tanto no Tratado da natureza humana quanto na Investigação sobre os princípios da moral. Nos limites do que são os objetivos deste texto, vamos priorizar a exposição daqueles elementos centrais, deixando em segundo plano as diferenças entre os argumentos expostos nos dois livros, e enfatizar a discussão sobre a justiça, quer seja pelo papel que Hume atribui a ela em relação à constituição da sociabilidade, quer seja pelo fato de que foi precisamente em relação a este tópico que Smith optou por preservar uma distância crítica em relação às conclusões formuladas por seu amigo.

Admitindo que o amor-próprio é um princípio importante da natureza humana - e, neste sentido, valorizando a contribuição mandevilleana à constituição de uma nova ciência do homem -, Hume rejeita, no entanto, as teorias que procuram reduzir todo sentimento moral àquele princípio (HUME, 2003: 108-9). Rejeita igualmente a opinião dos que atribuem todas as distinções morais ao resultado da educação ou dos artifícios criados por políticos hábeis para dirigir as paixões humanas em direção ao bem público (HUME, 2001: 540-1; 1978: 500). Nos dois casos, afirma, este tipo de teoria não é consistente com a experiência. Esta crítica é igualmente dirigida aos esforços dos racionalistas para apoiar as distinções morais em princípios transcendentes. De acordo com Hume, trata-se justamente de evitar fundar a filosofia sobre "hipóteses" e "invenções", a exemplo do que fizeram os pensadores da Antigüidade, mas, ao contrário, de buscar na natureza humana o fundamento de qualquer conclusão sobre a moral (HUME, 1993: 348).

A natureza humana é, para Hume (2003: xvii; 109), como que uma espécie de realidade última e definitiva, que não pode ser ultrapassada por nenhuma tentativa de explicação da moralidade e, neste sentido, algumas de suas qualidades devem ser tomadas como princípios originais. Ela repre-

\footnotetext{
${ }^{9}$ A discussão seguinte da filosofia moral de Hume está extensamente apoiada em Norton (1993) e, em alguns pontos, nas observações de Berry (1997: 129-132; 160-162) e Beauchamp (2003).
} 
senta, além disso, uma base estável e inalterável: seus princípios são necessários e uniformes entre os homens de diferentes nações e épocas, admitindo apenas pequenas diferenças de temperamento e caráter entre os indivíduos. Deste modo, é possível explicar o comportamento humano e predizer com razoável precisão as reações que brotam destes princípios:

"Existe um curso geral da natureza nas ações humanas, assim como nas operações do sol e do clima. Existem também caracteres peculiares a diferentes nações e a diferentes pessoas, e outros que são comuns a toda a humanidade. O conhecimento desses caracteres se funda na observação da uniformidade das ações deles decorrentes; e essa uniformidade constitui a própria essência da necessidade" (HUME, 2001: 439; 1978: 402-403).

Mas, além de apontar a existência de diferentes motivações para as ações humanas, Hume também afirma que é com base nelas que somos capazes de reconhecer ou não o mérito moral de cada ação. É verdade que, em geral, temos a impressão de que aquilo que provoca nossa aprovação ou desaprovação das ações de uma pessoa é o prazer ou desprazer que elas produzem para nós. Hume adverte, entretanto, que se alguém nos fere acidentalmente não se torna por esta razão nosso inimigo; de maneira semelhante, alguém que nos presta um serviço de modo inteiramente acidental não se constitui em nosso amigo. Ao contrário, nossa boa ou má disposição em rel ação a cada uma destas pessoas dependerá do propósito ou intenção que movem suas ações ou do seu caráter. Ao aprovarmos uma ação, consideramos apenas os motivos que a moveram e dirigimo-nos às qual idades morais que residem no interior do agente. ${ }^{10}$ Como não temos acesso direto a estas qualidades, fixamos nossa atenção sobre a ação, o "signo externo", que comparece aqui como um indicador dos princípios mentais e do caráter do agente (HUME, 2001: 382-3; 517-8; 1978: 348-9; 477-8).

Ainda segundo Hume, como nossa natureza é dotada de uma sensibilidade moral, as motivações do agente despertam em nós sentimentos que refletem sua motivação. A razão, por si só, não é capaz de servir de base para distinções morais. Seu papel é subordinado ao das paixões e pode consistir em apontar os meios para al cançar al gum objetivo, ou estabelecer em que medida um objetivo qualquer é factível, ou ainda, instruir sobre os efeitos de um determinado curso de ação para o agente e para a sociedade. Somos capazes de distinguir a virtude e o vício apenas com base no prazer ou dor que sentimos ao observar uma ação e as paixões que a movem. Este prazer ou esta dor, ressalte-se, são de um tipo peculiar, aquele que é capaz de nos fazer louvar ou condenar um caráter ou ação:

“Porque uma ação, sentimento ou caráter é virtuoso ou vicioso? Porque sua visão causa um prazer ou desprazer de um determinado tipo. Portanto, ao

\footnotetext{
${ }^{10} \mathrm{Se}$, entretanto, o que nos agrada ou desagrada em alguém não for uma ação sua, mas alguma qualidade constante e inerente ao seu caráter, então, afirma Hume, nossa disposição em relação a esta pessoa independerá de suas intenções.
} 
dar a razão desse prazer ou desprazer, estamos explicando de maneira suficiente o vício ou a virtude. Ter o senso da virtude é simplesmente sentir uma satisfação de determinado tipo pela contemplação de um caráter. (...) Não inferimos que um caráter é virtuoso porque nos agrada; ao sentirmos que nos agrada dessa maneira particular, nós de fato sentimos que é virtuoso" (HUME, 2001: 510-11; 1978: 471).

Investigando o prazer e a dor que distinguem o bem e o mal morais, Hume se interroga acerca dos princípios dos quais emergem a virtude e o vício: seriam eles princípios originais e naturais ou decorreriam de outros princípios, como a educação ou o interesse? Ao contrário do que se poderia esperar - isto é, ao invés de se alinhar com a opinião de Shaftesbury ou Hutcheson acerca deste ponto -, a resposta que Hume oferece no Tratado da natureza humana é cautelosa: "tudo depende da definição da palavra 'Natureza', que vem a ser a mais ambígua e equívoca que existe" (HUME, 2001: 513; 1978: 474). Tais princípios são naturais, afirma, no sentido de que não são miraculosos, ou ainda, de que não são raros e incomuns. Porém, se tomarmos por natural aquilo que é instintivo ou automático, contrastando-o com o que é artifício, com o que é inventado ou arquitetado, então teremos que al gumas virtudes são naturais, ao passo que outras são artificiais.

As primeiras - que, entre outras virtudes, incluem a benevolência, a ge nerosidade, a clemência e a moderação - são propensões intrínsecas à natureza humana. Porém, são também virtudes pouco poderosas e, muitas vezes, incapazes de sobrepujar os instintos voltados para o auto-interesse que são igualmente característicos de nossa natureza. N este sentido, as virtudes naturais ou sociais são insuficientes para sustentar a vida em sociedade; esta requer a existência de virtudes artificiais, como a justiça.

Não sendo intrínsecas ao homem, as virtudes artificiais evoluíram ao longo da história com base na natureza humana e nas relações interpessoais. Nos primeiros estágios do desenvolvimento da sociedade, estas relações estariam mais ou menos restritas ao círculo familiar e a vida em grupo poderia se apoiar no exercício da generosidade, ou seja, a sociabilidade poderia se basear apenas na afeição entre as pessoas, dispensando qualquer regra de justiça, qualquer sistema para reger a propriedade, pois "a afeição cordial torna tudo comum entre amigos; em especial, pessoas casadas abrem mão de sua propriedade uma em favor da outra, desconhecendo a distinção entre meu e teu" (HUME, 2001: 535; 1978: 495).

Porém, os homens buscam no desenvolvimento da sociedade uma maneira de compensar a debilidade de sua condição - isto é, a escassez dos recursos de que dispõem para atender suas carências e necessidades:

“Quando cada indivíduo trabalha isoladamente, e apenas para si mesmo, sua força é limitada demais para executar qualquer obra considerável; tem de empregar seu trabal ho para suprir as mais diferentes necessidades e, por isso, nunca atinge a perfeição em nenhuma arte particular; e como sua força e seu sucesso não são iguais o tempo todo, a menor falha em um dos dois 
deve inevitavelmente trazer para ele a ruína e a infelicidade" (HUME, 2001:

526; 1978: 485).

A sociedade é vantajosa para os homens na medida em que, trabalhando juntos, aumentam seu poder e suas habilidades e ficam menos expostos aos azares. Porém, segundo Hume, há obstáculos no temperamento natural dos homens e nas circunstâncias externas que se antepõem ao desenvolvimento da sociabilidade. Em primeiro lugar, os homens são dotados de um egoísmo (selfishness) que, embora não deva ser exagerado como querem "al guns filósofos", é uma qualidade que está presente na natureza humana em um grau suficiente para provocar conflitos com as paixões generosas e, deste modo, dar origem a ações conflituosas que colocarão em risco a existência da sociedade. Em segundo lugar, há o fato de que os bens que adquirimos pelo trabal ho ou pela boa sorte são escassos e podem ser tomados de modo violento, o que torna sua posse instável.

Dada a parcialidade natural de nossos afetos - isto é, o fato de que dirigimos nossa atenção prioritariamente a nós mesmos e aos nossos parentes, pouco nos ocupando dos que nos são estranhos - não há porque supor que a idéia da justiça pudesse inspirar naturalmente a conduta dos homens primitivos e remediar os obstáculos ao pleno florescimento da sociabilidade que acabamos de mencionar. A solução decorrerá, portanto, de um artifício, de uma convenção. De acordo com Hume (2001: 528-30; 1978: 487-489), durante suas primeiras experiências de vida em sociedade os homens observam as vantagens que poderiam extrair de sua associação e, agindo em consonância com este interesse, decidem restringir o "movimento cego e impetuoso" de suas paixões para permitir que cada um desfrute com segurança daquilo que adquiriu pelo trabal ho ou por sua boa sorte. Importa notar que o surgimento desta convenção prescinde de que os homens a expressem na forma de uma promessa:

“Observo que será de meu interesse deixar que outra pessoa conserve a posse de seus bens, contanto que ela aja da mesma maneira em relação a mim. Ela tem consciência de um interesse semelhante em regular sua conduta. Quando esse senso comum do interesse se exprime mutuamente e é conhecido por ambos, produz uma resolução e um comportamento adequados" (HUME, 2001: 530; 1978: 490).

O problema com esta maneira de explicar o surgimento da justiça reside no fato de que ela é apresentada como o resultado de um comportamento auto-interessado. Sendo assim, por que considerar a justiça uma virtude? De acordo com Hume, nos primórdios da vida em sociedade, o interesse que os homens têm na existência de regras que tornam a propriedade e o comércio mais seguros é o fator que assegura que estas mesmas regras sejam efetivamente observadas. Porém, com o crescimento da sociedade, a percepção deste interesse torna-se mais remota e difícil, fazendo com que alguns indivíduos terminem por violar aquelas regras. Naturalmente, no- 
tamos que somos prejudicados quando estes atos de injustiça nos atingem direta ou indiretamente; mas, mesmo quando a injustiça não nos atinge, ela ainda assim nos desagrada porque a consideramos prejudicial à sociedade humana e danosa àqueles que são afetados. Há, neste último caso, uma mudança importante: o que de início era uma preocupação com a manutenção da justiça motivada exclusivamente pela consideração do autointeresse torna-se uma preocupação com vistas ao interesse dos outros. Esta passagem, este movimento no qual meus sentimentos são mobilizados por algo que acontece a um estranho resulta da "qualidade mais notável" da natureza humana: "nossa propensão a simpatizar com os outros e a receber por comunicação suas inclinações e sentimentos, por mais diferentes ou até contrários aos nossos" (HUME, 2001: 351; 1978: 316).

Para Hume, a simpatia é o princípio que nos permite converter idéias em impressões: temos, de início, uma idéia das paixões de outra pessoa através de seus sinais externos, mas esta idéia se converte imediatamente em uma impressão "e adquire um tal grau de força e vivacidade que acaba por se transformar na própria paixão, produzindo uma emoção equivalente a qualquer afeto original" (HUME, 2001: 352; 1978: 317). Por meio desta operação, compartilhamos do desprazer sentido por al guém que sofre uma injustiça:

“e como tudo que produz um desprazer nas ações humanas, examinado de
maneira geral, é denominado Vício; e tudo que produz satisfação, da mes-
ma maneira, é dito Virtude, essa é a razão por que o senso do bem e do mal
morais resulta da justiça e da injustiça. (...) A ssim, o interesse próprio é
motivo original para o estabelecimento da justiça, mas uma simpatia com o
interesse público é a fonte da aprovação moral que acompanha essa virtu-
de" (HUME, 2001: 540; 1978: 499-500).

É fato que em trabalhos posteriores, particularmente na Investigação sobre os princípios da moral, Hume deixou de recorrer ao princípio da simpatia para formular sua concepção da justiça, preferindo referir-se a um princípio de humanidade ou de companheirismo (humanity or fellow-feeling) para com os outros. Este seria um dado incontornável da natureza humana que nos impediria de permanecer indiferentes à felicidade ou à miséria al heias (HUME, 2003: 109). Naquela obra, Hume também descartou a distinção entre virtudes naturais e artificiais mas reteve em boa medida as razões em que residiram esta diferenciação: na Investigação a justiça segue sendo apresentada como o resultado de uma convenção sem a qual a sociedade não poderia existir (cf. HUME, 2001: 538; 1978: 497; 2003: 94; BERRY, 1997: 162; Beauchamp, 2003: 35-38). Para nossos propósitos, mais do que investigar em detal he as diferentes maneiras como Hume aborda estas questões em seus trabal hos, o que importa, sobretudo, é analisar os desdobramentos deste debate na obra de Smith. É o esforço de compreender sua anál ise sobre a natureza da moral idade e da sociabilidade que nos ocupará no restante deste ensaio. 
Como dissemos acima, o projeto de Adam Smith, e dos filósofos morais escoceses, consistiu em realizar para a filosofia moral e para os fenômenos sociais aquilo que Isaac N ewton fizera no domínio da filosofia da natureza. Se o último desvelara as conexões ocultas que unem os vários fenômenos naturais, Smith pretendeu revelar os princípios que conectam e ordenam a vida em sociedade. Sua admiração pela obra de Newton nunca fora velada, tendo se expressado em diferentes contextos. ${ }^{11}$ Para ele, a tarefa da filosofia era explicar os vários fenômenos, quer naturais ou morais, a partir de princípios bem conhecidos ou provados, de modo a alcançar aquele prazer de "ver os fenômenos que considerávamos os mais inexplicáveis todos deduzidos de algum princípio (normalmente um princípio bem conhecido) e todos unidos em uma cadeia..." (LRBL II.133-4).

Se os pensadores escoceses viam a si mesmos como newtonianos - e, como tais, devotados a demonstrar empiricamente as regularidades que caracterizam a natureza e a sociedade -, para a grande mai oria deles, bem como para Newton, tais princípios refletiriam o plano (design) de um grande artífice, aquele que planejou e executou essa obra (handiwork), um ser divino (Haakonssen, 2003: 206). ${ }^{12}$ Seguindo uma analogia freqüente entre os autores da Modernidade, Deus estaria para o universo assim como o relojoeiro está para o relógio. A mão divina arranjaria e poria em movimento as peças que compõem a natureza. Para nós, os espectadores de sua obra, essa mão é invisível e apenas podemos acompanhar o resultado de seu trabal ho, assim como só podemos observar o movimento dos ponteiros do relógio, mas não podemos distinguir as mãos daquele que reuniu suas peças (EVENSKY, 1993: 199).

Este argumento era facilmente associável a uma visão providencialista, segundo a qual a humanidade é candidata a formar uma comunidade moral ordenada, no sentido de que cada indivíduo tem o potencial de atingir a perfeição moral da natureza humana, potencial que irá se realizar na medida em que cada um compreenda esta possibilidade. Formar uma comunidade moral é a um só tempo o objetivo e o estímulo natural para que cada um busque seu próprio desenvolvimento moral: caberia à filosofia moral

\footnotetext{
${ }^{11}$ Ver, a propósito, as considerações de Smith sobre o método e a filosofia natural de Newton nas suas lições sobre retórica (LRBL ii.133-134) e no ensaio sobre a história da astronomia (ASTRONOMY IV.67). Para uma discussão do método newtoniano de Smith, ver Cerqueira (2006b).

${ }^{12}$ Adam Ferguson, por exemplo, observa que "os poderes físicos empregados sucessiva ou conjuntamente e combinados a um propósito salutar constituem aquelas provas genuínas de um plano das quais inferimos a existência de Deus. $E$, sendo admitida esta verdade, não mais procuramos pela fonte da existência, podemos apenas compilar as leis que o Autor da natureza estabeleceu. E nas nossas mais recentes descobertas, bem como nas mais antigas, apenas apreendemos uma forma de criação ou providência até então desconhecida" (FERGUSON, 1995: 12).
} 
descortinar esta possibilidade para as pessoas - e, nesta exata medida, estimular sua realização -, mostrando a cada um o papel que desempenha na consecuução do desígnio divino (HAAKONSSEN, 2003: 207). Neste sentido, o plano divino é não apenas uma norma ética para a qual tendem as sociedades, mas também um padrão analítico em relação ao qual o estágio evolutivo de cada sociedade pode ser avaliado (EVENSKY, 1989: 243-5).

Como vimos, este tipo de concepção, ligada a um argumento teleológico sobre a existência de Deus, foi aplicada à filosofia moral pelos discípulos de Newton, e não apenas por Turnbull, mas também por Shaftesbury, Joseph Butler, Lord Kames, Francis Hutcheson e, mais tarde, Dugald Stewart. Esta mesma concepção foi o ponto de partida para que os pensadores escoceses dessem início às suas investigações empíricas sobre as instituições sociais e econômicas efetivamente existentes. Mas, se esta preocupação em encontrar uma explicação empírica para as formas sociais representa um consenso entre os escoceses, sua adesão ao providencialismo - e, por conseqüência, àquela concepção que enfatiza o papel prescritivo que a filosofia deve cumprir em relação a moralidade - deve ser objeto de análise individualizada. Como afirmamos anteriormente, se a maior parte destes pensadores concebia a existência de uma ordem natural inscrita na criação pela providência divina, havia também exceções notáveis à regra, das quais Hume representa o caso mais notório e explícito. Para ele, a ordem social poderia ser explicada sem o recurso a qualquer tipo de interferência divina, apenas como o resultado não-intencional das ações humanas, tal como buscara explicar a emergência da justiça e sua conversão em virtude (HAAKONSSEN, 1981: 20). Nos Diálogos sobre a religião natural - cuja publicação póstuma Hume desejou confiar a Smith, que, temeroso da repercussão de seus argumentos, declinou da responsabilidade - ele rejeita o argumento teleológico sugerindo que não podemos saber quão perfeito é este mundo: ele bem pode ser defeituoso e imperfeito, criado por alguma divindade infantil ou inferior que, envergonhada diante do resultado obtido, abandonou sua obra à própria sorte e ao escárnio dos deuses superiores. Sendo este o único universo que conhecemos, não há como saber quão perfeito ele é; supô-lo perfeito representaria, na verdade, uma petição de princípio (BERRY, 1997: 174).

A este respeito, a compreensão da obra de Smith apresenta dificuldades consideráveis, que redundaram numa grande variedade de leituras entre seus intérpretes. Ao longo da Teoria dos sentimentos morais, deparamonos mais de uma vez com trechos como este:

"A felicidade da humanidade, bem como de todas as outras criaturas racionais, parece ter sido o propósito original projetado pelo Autor da natureza, quando ele as trouxe à existência. (...) E essa opinião (...) é ainda mais confirmada pelo exame dos trabalhos da natureza, que parecem todos projetados para promover a felicidade e proteger contra a miséria. Mas, agindo de acordo com os ditames de nossas faculdades morais, perseguimos necessariamente os meios mais eficazes para promover a felicidade da 
humanidade e pode-se dizer, portanto, que, em certo sentido, cooperamos com a Divindade e promovemos, tanto quanto está em nosso poder, o plano da Providência" (TM S III.v.7).

Passagens como esta poderiam sugerir à primeira vista que, no que diz respeito ao providencialismo, deveríamos tratar a obra de Smith ao lado de Hutcheson e em oposição ao pensamento de Hume. Porém, toda a dificuldade reside justamente em saber que peso devemos atribuir às passagens em que Smith invoca a presença do "grande Diretor da Natureza" (great Director of nature), do "Autor da natureza" (A uthor of nature), da "Providência" (Providence) ou de sua "mão invisível" (invisible hand). ${ }^{13}$

Por um lado, intérpretes como Wilhel m Hasbach consideraram que o ponto de partida da teorização de Smith é a crença numa divindade sábia e benevolente cuja obra, estruturada ao modo de um mecanismo, tem por finalidade promover a felicidade humana: "o Criador assemelha-se a um relojoeiro que, de maneira engenhosa, reuniu as engrenagens do mundo para produzir ordem, harmonia, beleza e felicidade, sem que as engrenagens soubessem ou desejassem este resultado" (Hasbach apud Kleer, 1995: 275). Referindo-se à Teoria dos sentimentos morais, Jacob Viner também sugere que nela encontramos uma "doutrina incondicional de uma ordem natural harmoniosa, sob direção divina, que promove o bem-estar do homem através da operação de suas propensões individuais" (VINER, 1966: 125). ${ }^{14}$

Mais recentemente, Macfie (1967: 102) sugeriu que as passagens em que Smith referese à Providência estão geralmente desconectadas do argumento principal de sua filosofia moral - a saber, o argumento sobre a simpatia e o espectador imparcial - mas insiste que o sistema smithiano comporta uma idéia de harmonia natural que subjaz ao argumento da mão invisível que estaria ancorada na fé pessoal de Smith num Deus benevolente.

Noutro extremo, intérpretes como H aakonssen (2003: 207) aproximam Smith de Hume, afirmando que ambos seriam enfaticamente contrários às explicações teleológicas. Para ele, Hume teria recusado qualquer explicação de tipo providencialista para a vida em sociedade, ao passo que Smith preocupouse em explicar a suscetibilidade do homem a este tipo de explicação, deixando de lado a questão sobre sua validade. Neste sentido, ambos encarariam a formação da sociedade como um fato empírico, destituído de qualquer valor transcendental ou de qualquer sentido moral prescritivo em si mesmo.

Diante destas diferentes compreensões, parece mais prudente tomar uma posição intermediária, como aquela apresentada por Campbell (1975: 8182). Trata-se de reconhecer que, ao mesmo tempo em que subscreve o argumento teleológico sobre a existência de Deus, Smith raramente faz uso

\footnotetext{
${ }^{13}$ Respectivamente, nos seguintes parágrafos: TMS II.i.5.10; II.iii.3.2; III.5.7; IV. 1.10. ${ }^{14}$ Por outro lado, o mesmo Viner (1966: 126-7) sustenta que a ênfase numa divindade benevolente estará praticamente ausente na Riqueza das nações.
} 
dele. Explicações em termos da vontade divina só comparecem quando a investigação em termos das causas eficientes já foi completada. Neste sentido, a explicação teleológica surge como um complemento - e não como um substituto - de explicações causais. Depois que o mecanismo causal foi apontado e o resultado (não-intencional) de seu funcionamento é benéfico para a sociedade, entra em cena o argumento teleológico, que atribui este resultado ao plano divino. Convém notar, entretanto, que nem toda conseqüência imprevista ou não-intencional do funcionamento da sociedade será benéfica (BERRY, 1997: 46-47).

\section{A simpatia e o espelho da sociedade}

Em uma passagem de sua Breve introdução a filosofia moral, Hutcheson afirma que os homens parecem dotados de uma tal profusão de desejos e paixões que, diante de visão tão complexa, a natureza humana deve parecer à primeira vista "um estranho caos ou uma confusa combinação de princípios dissonantes, até que, por uma consideração mais atenta, descubramos al guma conexão ou ordem natural entre eles, alguns prinápios natural mente adaptados a regular todos os demais" (HUTCHESON, 1990: 36). Para Smith, assim como para seu mestre e antecessor em Glasgow, o "inesquecível Dr. Hutcheson", a "ciência que procura investigar e explicar aqueles princípios conectantes éa que é propriamente chamada de filosofia moral" (W N V.i.f.25).

Mas, em relação ao modo como Smith concebe a moralidade, há uma grande distância em relação às posições defendidas por Hutcheson. Isto pode ser constatado, desde logo, na maneira como Smith se posiciona em relação àquele debate secular sobre o qual nos detivemos no início deste texto, vale dizer, a controvérsia que opôs, de um lado, os defensores da moralidade como algo intrínseco ou natural aos homens e, de outro, os adeptos da visão que concebe a moralidade como um artifício criado para controlar ou regular o potencial disruptivo das paixões humanas. $\mathrm{Na}$ verdade, mais do que se posicionar a favor desta ou daquela corrente, Smith oferece uma resposta que, de certo modo, irá implodir os próprios termos do debate. Seguindo aqui a leitura proposta por Haakonssen (2003; 2002), pode-se afirmar que a contribuição mais original de Smith à filosofia moral foi justamente a de ter removido a linha divisória entre natureza e artifício. Radicalizando o argumento de Hume, Smith argumentou que não apenas a justiça, mas o conjunto da moralidade sobrevém à natureza humana de uma maneira semel hante àquela descrita por Hume ao explicar o surgimento da justiça. Neste sentido, Smith rejeita a distinção entre virtudes naturais e artificiais e associa intimamente a moralidade à sociabilidade:

“Pode-se dizer que Smith sugeriu que a moral idade em geral era 'artificial'

- mas que ela era um artifício que, por assim dizer, era 'natural' para a humanidade. (...) No âmago do complexo argumento de Smith estava a 
idéia de que a personalidade das pessoas, sua habilidade de serem agentes autoconscientes vis-à-vis outras pessoas e vis-à-vis a seu próprio eu passado e futuro, era algo adquirido no intercurso com os outros" (Haakonssen, 2003: 211-2).

Smith recusa, portanto, a idéia de um estado de natureza que, histórica ou conceitualmente, anteceda à condição civil (artificial) da humanidade e reduz toda a moralidade a uma convenção que resulta da vida em sociedade. Ao mesmo tempo, torna este artifício - a produção de convenções morais - uma condição natural para a humanidade.

Seu ponto de partida, é admitir que os homens estão dotados de um conjunto variado de sentimentos. N ossas experiências sensíveis atuam sobre eles, que, por sua vez, determinam nossas reações e comportamentos. 0 que importa frisar é que, para Smith, os diferentes sentimentos não são em si mesmos bons ou maus. Com efeito, ele reconhece que o amor-próprio (self-love) é um princípio natural nos homens, que nos permite garantir e aperfeiçoar nossa existência: "sem dúvida, todo homem é por natureza recomendado, primeira e principalmente, ao cuidado de si mesmo; e como ele é mais apto ao cuidado de si mesmo que ao de alguma outra pessoa, é apropriado e correto que seja assim" (TM S II.ii.2.1).

Mas, para Smith, ao mesmo tempo que os homens são inclinados a buscar seus interesses pessoais, eles também se preocupam com os outros homens, com sua felicidade ou seu sofrimento: "por mais egoísta que se possa admitir que o homem seja, existem evidentemente al guns princípios em sua natureza que o fazem interessar-se pela sorte de outros e tornam sua felicidade necessária para ele mesmo, apesar de não obter nada disso, a não ser o prazer de assisti-la" (TM S I.i.1.1). Portanto, como seres naturalmente dispostos para a vida em sociedade, nem mesmo o menos virtuoso dentre os homens consegue ser indiferente ao que se passa com os demais, a sua al egria ou sua dor, e este interesse pela sorte alheia não decorre de qualquer consideração da utilidade que podemos extrair desta situação. Isto é o que a experiência nos ensina: "é um fato óbvio demais para predisar ser comprovado" que nos emocionamos diante da visão do sofrimento alheio (TM S I.i.1.1).

Como não temos acesso direto aos sentimentos dos outros homens, afirma Smith, só podemos formar uma idéia da maneira como eles se sentem ao imaginarmos como é que nos sentiríamos se estivéssemos em sua posição. Este sentimento de solidariedade (fellow-feeling), quer pela dor, quer por algum outro sentimento dos outros seres humanos é o que Smith denomina de simpatia (sympathy), um princípio "bem conhecido" e que ocupa uma posição-chave em sua filosofia moral, pois é com base nele que podemos conectar todos os demais princípios da moralidade, dando conta dos "fenômenos que considerávamos os mais inexplicáveis".

Seja por ocupar uma posição privilegiada na Teoria dos sentimentos morais, seja por ter sido objeto de muita controvérsia e mal-entendido entre 
os seus intérpretes, é conveniente que o sentido deste conceito de simpatia seja aqui precisado. Como se sabe, seu emprego na filosofia remonta à Antigüidade: dos estóicos até o Renascimento, foi usado sobretudo para se referir a uma conexão orgânica entre objetos do mundo físico, que se constituiria no fundamento da magia (ABBAGNANO, 1998: 901). Esse não é, entretanto, o sentido preciso que o conceito assume na filosofia moral de Smith, ainda que seja razoável afirmar que, para ele mesmo, a idéia de simpatia (bem como a de uma harmonia natural) estivesse ligada ao ponto de vista adotado pelos estóicos.

A rigor, é possível encontrar ao longo da Teoria dos sentimentos morais três sentidos distintos atribuídos ao termo simpatia (Otteson, 2002: 17-18). O primeiro a comparecer no texto, é exatamente aquele de um sentimento de solidariedade que se manifesta na forma de um interesse pela sorte dos outros homens. À primeira vista, tem-se a impressão de que o conceito está referido apenas à compaixão ou piedade pelo sofrimento alheio - que corresponde ao segundo sentido com o qual a palavra comparece no texto. Mas Smith logo esclarece que o significado do conceito de simpatia é mais amplo, referindo-se também ao compartilhar de qualquer outro tipo de emoção sentida por alguém:

"Piedade e compaixão são palavras que, com propriedade, denotam nossa
solidariedade pelo sofrimento alheio. Simpatia, embora talvez originalmen-
te seu significado fosse o mesmo, pode agora ser usada sem grande impro-
priedade para denotar nossa solidariedade com qualquer paixão" (TM S
l.i.1.5).

Como foi dito, este uso - que, na verdade, corresponde à etimologia da palavra (comunidade de sentimentos, sentir o mesmo que outrem) - engloba a segunda maneira como o conceito aparece ao longo da obra de Smith, isto é, como sinônimo de piedade ou compaixão, emoções que sentimos diante do sofrimento al heio: "a palavra simpatia, em seu significado mais apropriado e original, denota nossa solidariedade para com os sofrimentos, e não para com as alegrias de outros" (TM S I.iii.1.1). Mas o conceito adquire maior precisão na terceira forma em que é empregado, aquela sobre a qual Smith vai edificar sua teoria moral: neste uso, a palavra simpatia denota uma correspondência de sentimentos entre a pessoa diretamente afetada e aquele que observa atentamente a situação, o espectador.

O que foi dito até aqui permite desfazer alguns equívocos mais simples, embora comuns, sobre o conceito de simpatia. Em primeiro lugar, ele não se restringe à compaixão ou piedade e, neste caso, é mais amplo que - e não se confunde com - qualquer forma de benevolência. Em segundo lugar, naquele sentido mais estrito mencionado ao final do parágrafo anterior, a simpatia não é propriamente uma paixão, mas uma concordância ou correspondência de sentimentos (cf. TM S I.i.3.1-3; Otteson, 2002: 18). ${ }^{15} \mathrm{Em}$

${ }^{15}$ Naturalmente, nos outros dois sentidos o conceito denotará uma paixão. 
terceiro lugar, o conceito de simpatia, tal como proposto por Smith, é mais complexo e amplo que aquele adotado por Hume. Este último definira a simpatia como o ato de compartilhar da dor ou do prazer produzidos por alguma ação em uma outra pessoa. Para Smith, a simpatia refere-se ao compartilhar de qualquer sentimento e, mais do que isso, não decorre de um "contágio" de sentimentos, ${ }^{16}$ mas consiste num ato da imaginação:

“Como não temos experiência imediata do que os outros sentem, somente podemos formar uma idéia da maneira como são afetados se imaginarmos o que nós mesmos sentiríamos numa situação semelhante. (...) nossos sentidos jamais nos informarão sobre o que ele sofre. Pois não podem, e jamais poderão, levar-nos para além de nossa própria pessoa, e apenas pela imaginação nos é possível conceber em parte quais são as suas sensações. Tampouco esta faculdade pode nos ajudar senão representando para nós as próprias sensações se nos encontrássemos em seu lugar" (TM S I.i.1.2).

Aquilo a que temos acesso é apenas o que pode ser observado, as circunstâncias que cercam o agente, mas não sua mente. Portanto, a simpatia não decorre de observarmos a paixão efetivamente experimentada pelo agente, mas de nos colocarmos na situação que a provoca: neste sentido, podemos simpatizar com os heróis de tragédias e romances e, até mesmo, com os mortos (TM S I.i.1.4; 10; 13).

A isto Smith acrescenta que "nada nos agrada mais que observar em outros homens um sentimento solidário com todas as emoções de nosso próprio peito; e nada nos choca mais que a aparência do contrário" (TM S I.i.2.1). Este prazer é espontâneo e não pode ser atribuído a qualquer consideração relativa a algum interesse pessoal (TM S I.i.2.1-2). Além disso, é com base nesta correspondência de sentimentos que podemos formular avaliações morais: quando as paixões da pessoa diretamente afetada estão em consonância com as paixões que o espectador produz em si mesmo através da simpatia (ou seja, imaginando-se na mesma situação da pessoa afetada), então o espectador é movido a considerar aquelas paixões como necessariamente próprias ou adequadas. O contrário ocorre quando as paixões produzidas através da simpatia diferem daquilo que a pessoa efetivamente sente: elas nos parecerão necessariamente inadequadas ou impróprias: "portanto, aprovar as paixões de um outro como adequadas a seus objetos é o mesmo que observar que simpatizamos inteiramente com elas; e não aprová-las como tal é o mesmo que observar que não simpatizamos inteiramente com elas" (TM S I.i.3.1).

Smith ilustra seu argumento fazendo notar que aquele que, em minha companhia, ri da mesma piada que eu, não pode deixar de considerar meu riso adequado e, como tal, aprová-lo. Ao contrário, aquele que não sente

\footnotetext{
${ }^{16}$ Hutcheson (1990: 14) refere-se a simpatia como uma "espécie de contágio ou infecção" ("a sort of contagion or infection") e Hume (1994: 83) fala da simpatia como um "contágio de costumes" ("contagion of manners") (cf. Berry, 1997: 162-163).
} 
a mesma emoção, ou não a sente com a mesma intensidade, não pode deixar de desaprovar meus sentimentos: se eu rir alto enquanto ele não ri ou apenas sorri, esta dissonância fará com que ele desaprove meus sentimentos. Portanto, aprovar ou desaprovar as paixões de al guém é o mesmo que observar sua concordância ou discordância com as nossas (TM S I.i.3.12). Poder-se-ia objetar que nem sempre a aprovação vem acompanhada desta simpatia ou coincidência de sentimentos: como quando aprovamos o riso de alguém após ouvir uma piada, embora nós mesmos não estejamos rindo, seja por estarmos de mau humor, seja por estarmos distraídos. Ainda assim, responde Smith, é fácil ver que mesmo nestas situações a nossa aprovação se apóia em última instância em uma simpatia, em uma correspondência de sentimentos: aprovamos o riso do outro e sentimos que ele é apropriado ao seu objeto (neste caso, à piada) porque, apesar de não podermos compartilhar do riso naquele momento de mau humor, percebemos que isso ocorreria na maioria das vezes, "porque a experiência nos ensinou que tipo de diversão é normalmente mais capaz de nos fazer rir, e observamos que essa é uma delas" (TM S I.i.3.3; grifo nosso).

Respondendo a outra objeção - a crítica formulada por Hume (Corr. 36), que sugeriu existir uma incompatibilidade entre a natureza necessariamente agradável do sentimento de aprovação e o fato de que podemos simpatizar com sentimentos desagradáveis (como a dor al heia) - Smith procurou esclarecer melhor, na segunda edição da Teoria dos sentimentos morais, a relação entre a correspondência de sentimentos e a aprovação moral que dela decorre:

“Respondo que há dois aspectos a considerar no sentimento de aprovação: primeiro, a paixão solidária do espectador; segundo, a emoção suscitada ao observar a perfeita reciprocidade entre esta paixão solidária nele mesmo e a paixão original na pessoa diretamente afetada. Esta última emoção, em que consiste propriamente o sentimento de aprovação, é sempre aprazível e agradável. A outra pode ser tanto agradável, quanto desagradável, de acordo com a natureza da paixão original, cujos traços deve sempre em alguma medida reter" (TM S I.iii.1.9 nota). ${ }^{17}$

Deste modo, é possível concluir que, para Smith, é através da simpatia portanto, de uma operação da imaginação - que os homens constituem a esfera da moralidade. Quando os homens de "todas as eras e países do mundo", observaram "as características, os desígnios e as ações uns dos outros" (WN V.i.f.25), foram levados a ordenar através da imaginação estas experiências. Se em relação aos objetos naturais a imaginação desempenha o papel de impor uma ordem e coerência entre fenômenos aparentemente desconexos, neste caso, mais do que ligar acontecimentos, dotar os fenô-

${ }^{17}$ Apesar desta qualificação, é preciso admitir que, em várias passagens, Smith comete deslizes de linguagem, usando o conceito de simpatia para expressar o sentimento de aprovação propriamente dito (Haakonssen, 2002: 14). 
menos humanos de ordem e coerência é algo que depende de sermos capazes de atribuir ações a agentes. Isto é o que fazemos quando julgamos compreender o propósito que move a pessoa a agir. Como não temos acesso à sua mente, mas apenas às circunstâncias observáveis e ao próprio comportamento, a imaginação busca impor uma ordem aos acontecimentos percebidos e o faz atribuindo motivos imaginários para aquele comportamento observado. É, portanto, através deste ato da imaginação que os outros homens tornam-se, aos olhos do espectador, verdadeiros agentes, seres morais, pessoas imputáveis por seus atos (HAAKONSSEN, 2002: 14).

\section{o espectador imparcial e a virtude da justiça}

Mas é também através da simpatia que nós mesmos nos tornamos agentes morais: só nos tornamos autoconscientes através de nossas relações com outros indivíduos. Ao mesmo tempo em que os observamos, sabemos que somos observados por eles e, nesta medida, somos movidos a buscar aquele prazer genuíno de perceber nas pessoas que nos rodeiam um sentimento de solidariedade para com nossas emoções, da mesma maneira que nos atormentamos quando isso não ocorre (TM S I.i.2.1).

Como estamos cientes do risco de que esta concordância de sentimentos não ocorra, pois cada um de nós se coloca de um ponto de vista distinto em relação aos acontecimentos e pessoas, nossa imaginação anseia por evitar que esterisco se concretize. Evitar uma eventual dissonância desentimentos implica estabelecer um acordo, uma ordem, em relação a nossos comportamentos: somos levados pela simpatia a antecipar a avaliação que os outros farão de nós e, deste modo, ajustamos previamente nosso comportamento de modo a evitar que o conflito se concretize (HAAKONSSEN, 2002: 15).

Assim, como sabemos que os outros homens não são capazes de sentir nossas emoções com a mesma intensidade que nós, somos levados a moderar nossos sentimentos para que os demais possam compartilhar deles e exibir sua simpatia para conosco. Ou seja, somos levados a conhecer e moderar nossos sentimentos, projetando-nos no lugar dos outros para procurar compreender como eles nos percebem, de modo a tornar nossos sentimentos mais próximos dos deles: "Para Smith, a origem de nossa habilidade para controlar nossas paixões repousa nessa capacidade autoreflexiva de enxergar nossa situação através dos ol hos dos outros que estão intrinsecamente menos interessados nela" (MULLER, 1995: 102). Internalizamos o espectador e, através deste ato da imaginação, procuramos nos ver como as outras pessoas nos veriam para saber se simpatizariam com nossos sentimentos e motivos ou não, de modo a poder ajustar nosso comportamento. A sociedade constitui, por assim dizer, um espelho através do qual tomamos consciência de nós mesmos como agentes mo- 
rais. É a esta conexão entre a sociabilidade e a moralidade que Smith faz referência numa passagem que, mesmo longa, vale a pena citar, pelo contraponto que estabelece com outras concepções:

\begin{abstract}
"Se fosse possível que uma criatura humana vivesse em algum lugar solitário até alcançar a idade madura, sem qualquer comunicação com sua própria espécie, não poderia pensar em seu próprio caráter, a conveniência ou demérito de seus próprios sentimentos e conduta, a beleza e deformidade de seu próprio espírito, mais do que na beleza ou deformidade de seu próprio rosto. Todos esses são objetos que não pode facilmente ver, para os quais não olha, e com relação aos quais carece de espelho que sirva para apresentá-los a sua vista. Tragam-no para a sociedade e será imediatamente provido do espelho que carecia. É colocado ante o semblante e comportamento daqueles com quem vive (...) que pela primeira vez verá a conveniência ou inconveniência de suas paixões, a beleza ou deformidade de seu espírito. (...) Cuidará que a humanidade aprova algumas [de suas paixões], e se enoja com outras. Num caso se sentirá exaltado, abatido em outro; seus desejos e aversões, alegrias e tristezas freqüentemente se converterão, ago$\mathrm{ra}$, em causas de novos desejos e novas aversões, novas alegrias e novas tristezas e, por isso, agora Ihe interessarão profundamente e, muitas vezes, ocuparão sua mais atenta consideração" (TM S III.i.3).
\end{abstract}

Neste sentido, Smith considera que cada homem é levado em sua busca pela simpatia dos demais a moderar seus sentimentos, inclusive o seu amor-próprio, pois aprende a julgar suas ações tal como elas devem parecer aos outros, ou ainda, tal como elas pareceriam a um "espectador imparcial" (impartial spectator). Este último, não é o espectador externo, mas um espectador interno, "o homem dentro do peito, o grande juiz e árbitro" (TM S III.2.32), criado pela imaginação de cada homem para julgar sua conduta tal como ela apareceria a alguém que não fosse limitado pelos preconceitos, pela parcialidade ou pela desinformação que, muitas vezes, caracterizam o ponto de vista dos espectadores externos. Ele é o próprio eu, mas não na condição de agente, e sim na condição de observador de si mesmo. Neste sentido, ele é identificado por Smith como o princípio que explica a consciência.

Tendo mostrado que a moralidade se constitui num processo de aprendizado na vida em sociedade, Smith evita através do recurso ao espectador imparcial reduzir o critério moral à conformidade com a opinião pública, preservando uma distinção entre eles. A consciência não se limita refletir as atitudes que prevalecem em dado instante na sociedade, mas ao contrário se choca muitas vezes com a opinião popular: é apenas consultando o espectador imparcial - o "grande habitante do peito humano" ou o "juiz interior" - "que podemos ver o que nos diz respeito em sua forma e dimensão apropriadas, que podemos estabelecer uma comparação apropriada entre nossos interesses e o de outras pessoas" (TM S III.3.1). A través dele, estabelecemos uma referência a partir da qual podemos julgar a nós mesmos e aos demais (BERRY, 1997: 164-5; RAPHAEL, 1975: 90ss.). 
É através deste padrão ideal, ou ainda, do balanço entre o que nos dita o nosso amor-próprio e aquilo que nos recomenda o nosso desejo de que os outros simpatizem conosco, que Smith é capaz de derivar aquela virtude - herdada dos estóicos - que ocupa um lugar destacado em sua filosofia moral: o autodomínio (self command), ou seja, "aquele domínio das paixões que submete todos os movimentos da nossa natureza ao que a nossa própria dignidade e honra, e a correção de nossa própria conduta requerem..." (TM S I.i.5.1).

Este mesmo autodomínio está na base da possibilidade de manter a ordem social, prescindindo em larga medida de um controle direto do Estado, pois cada indivíduo tem em si um motivo para observar as normas de comportamento adequadas. Cada indivíduo deriva de sua relação com o espectador imparcial aquela virtude mínima a partir da qual a vida em sociedade se torna possível, o sentido de justiça:

"Todos os membros de uma sociedade humana precisam cada um do auxílio dos outros e estão, da mesma maneira, expostos a danos mútuos. A sociedade floresce e é feliz onde o auxílio necessário é fornecido reciprocamente pelo amor, gratidão, amizade e estima. (...) [Por outro lado] a sociedade pode subsistir entre homens diferentes, assim como entre diferentes comerciantes, por uma compreensão de sua utilidade, sem qualquer amor ou afeição mútuos. (...) A sociedade, entretanto, não pode subsistir entre aqueles que estão sempre prontos para prejudicar e lesar uns aos outros" (TM S II.ii.3.1-3).

Desse modo, se a caridade (beneficence) é uma virtude superior, pois consiste em promover a felicidade dos outros e permite à sociedade florescer e ser feliz, não se deve, no entanto, esperar que todos os homens ajam em relação aos demais com essa motivação desinteressada e nem isso é condição para que a sociedade exista. O requisito para a existência da sociedade consiste apenas na virtude da justiça: “A caridade, portanto, é menos essencial para a existência da sociedade que a justiça. A sociedade pode subsistir sem a caridade, ainda que não no estado mais satisfatório; mas o predomínio da injustiça deve destruí-la inteiramente" (TM S II.ii.3.3).

A virtude da justiça consiste naquele sentido de imparcialidade que emerge de nosso diálogo com o espectador imparcial. Ela depende, portanto, da nossa capacidade de avaliar os efeitos de nossas ações colocando-nos no lugar daqueles a quem podemos ofender:

"Perturbar a felicidade dele [a de um outro homem] apenas porque ela encontra-se no caminho da nossa, tirar dele aquilo que lhe é realmente útil apenas porque pode ser tão ou mais útil para nós, ou favorecer, dessa maneira, às custas de outras pessoas, a preferência natural que cada homem tem por sua própria felicidade acima daquela de outras pessoas é aquilo com que nenhum espectador imparcial pode concordar" (TM S II.ii.2.1). 
Sem a justiça - aqui concebida de modo semel hante à tradição do direito natural, como o direito de cada um ao que é seu - a sociedade não pode existir. É com base nisso que o Estado deve fazer cumprir o direito de cada indivíduo a sua vida e propriedade, punindo aqueles que violam esta regra (TM S II.ii.3.6):

\begin{abstract}
“ Na corrida por riqueza, fama e honrarias, ele [o indivíduo] pode correr tão esforçadamente quanto for capaz, e empregar ao máximo cada nervo e músculo para ultrapassar todos os seus competidores. Mas se ele porventura atropela ou derruba qualquer um deles, a complacência dos espectadores termina por completo. Trata-se de uma violação do jogo limpo que eles não podem admitir. (...) Portanto, eles logo simpatizam com o ressentimento natural do prejudicado e o infrator torna-se o objeto de seu ódio e indignação" (TM S II.ii.2.1; cf. MULLER, 1995: 111).
\end{abstract}

É fácil ver, portanto, que a teoria da justiça proposta por Smith aproximase em mais de um sentido daquela exposta por Hume. Ambos concedem à justiça o papel de requisito indispensável para a vida em sociedade, assim como ambos a concebem como uma virtude negativa, porque tudo o que ela requer é a abstenção de qualquer violação do direito alheio: "freqüentemente, podemos cumprir todas as regras da justiça sentandonos quietos e não fazendo nada" (TM S II.ii.1.9). Porém, há uma importante diferença nestas duas abordagens que merece ser destacada. Se em Hume temos uma concepção "proto-utilitarista" da justiça, na medida em que ele faz esta virtude depender da apreensão de seu efeito positivo para o bemestar da sociedade, Smith, por sua vez, rejeita esta conexão. Para ele, não é a percepção dos riscos que práticas licenciosas acarretam para a sociedade que nos move a condená-las, até porque, afirma, poucos homens já refletiram sobre a necessidade da justiça para a existência da sociedade. Ao contrário, na maioria das vezes nossa consideração surge de uma simpatia com o ressentimento daquele que é ofendido em seus direitos e do prazer que sentimos em ver o culpado punido (TM S II.ii.3.9-10).

\title{
Notas conclusivas
}

Mais do que resumir a exposição e interpretação do argumento moral de Smith, gostaríamos de concluir sugerindo algumas conseqüências importantes do que foi dito para a compreensão daquele outro problema tantas vezes discutido: o da conexão entre sua filosofia moral e sua economia política. ${ }^{18}$

${ }^{18}$ Estes pontos são aqui apenas indicados. Seu desenvolvimento requereria, naturalmente, outros artigos. Para um esforço parcial e preliminar, ver Cerqueira (2004; 2005). 
Contra Hutcheson, para quem “o amor-próprio era um princípio que jamais poderia ser virtuoso em qualquer grau ou sentido", Smith é claro ao afirmar que "a consideração da nossa felicidade e interesse privados apresenta-se também, em muitas ocasiões, como princípios de ação bastante louváveis" (TM S VII.ii.3.12;16). O que conta na avaliação moral do amorpróprio é, como nos demais casos, a aprovação ou não deste sentimento pelo espectador imparcial. Deste modo, ele pode afirmar que "a negligência e a falta de economia são universalmente desaprovadas, não porque decorram da falta de benevolência, mas da falta de uma atenção adequada aos objetos do interesse próprio" (TM S VII.ii.3.16). Portanto, não há qualquer sentido em contrapor na obra de Smith a existência de uma esfera da economia movida pelo interesse pessoal e um domínio da moralidade em que as ações humanas são orientadas pela simpatia, como inúmeros intérpretes fizeram ao longo dos últimos dois séculos. ${ }^{19}$

Por outro lado, Smith se opôs claramente ao argumento que faz a aprovação moral de uma ação depender de seus resultados. Deste modo, ele não deve ser lido como um utilitarista à maneira de Bentham pois, como vimos, um dos aspectos que o afasta de Hume consiste em justamente rejeitar o argumento que vincula a aprovação moral da justiça aos bons resultados que ela traz para a sociedade (TM S IV.2). A base primordial para qualquer avaliação moral é sempre, para Smith, a intenção perseguida pelo agente, de tal modo que uma ação orientada por sentimentos impróprios não será moralmente boa mesmo que produza resultados positivos. Neste sentido, o fato de que ele constate que algumas ações contribuem para o bem público mesmo quando não tencionam fazêlo não deve ser confundido com uma aprovação moral das economias de mercado ou das sociedades comerciais. ${ }^{20}$ Diante do peso da influência do utilitarismo na formação e no desenvolvimento da economia política clássica e da economia neoclássica ao longo do século XIX, o que acabamos de afirmar deveria servir de alerta contra qual quer tentativa precipitada de ver na obra de Smith o momento fundador destas correntes teóricas. Sua apropriação pelos autores do século XIX foi, antes de tudo, seletiva, o que deixa em aberto a possibilidade de uma releitura de sua obra que faça justiça à abrangência e complexidade de sua visão.

${ }^{19}$ Ver, por exemplo, as leituras propostas por Buckle (1903; 304-330) e por Dumont (1977).

${ }^{20}$ Se há motivos para aprovar moralmente estas sociedades - o que, por si só, é algo discutível nos termos da teoria moral de Smith, na medida em que a aprovação moral concerne propriamente aos indivíduos, seus sentimentos e ações, e não a sociedades inteiras - eles não dizem respeito diretamente aos bons efeitos que decorrem de seu funcionamento. Ver, a propósito, Fleischacker (2004: 47ss.). 


\section{Referências bibliográficas}

ABBA GNANO, Nicola. D icionário de filosofia. Tradução de Alfredo Bosi, São Paulo: Martins Fontes, 1998 [1971].

BEA UCHAMP, Tom. Editor's introduction. In: HUME, David. An enquiry concerning the principles of morals. Oxford: Oxford University Press, 2003 [1998].

BERRY, Christopher. Social theory of the Scottish enlightenment. Edinburgh: Edinburgh University Press, 1997.

BUCKLE, Henry T.. History of civilization in England. (Volume III) London: Longmans, 1903.

CAMPBELL, T. D.. Scientific explanation and ethical justification in the Moral Sentiments. In: WILSON, Thomas; SKINNER, Andrew (ed.). The market and the state: essays in honour of Adam Smith. Oxford: Clarendon Press, 1975.

CERQUEIRA, Hugo. Adam Smith e o surgimento do discurso econômico. Revista de economia política, v. 24(3): 422-441, 2004.

CERQUEIRA, Hugo. Para ler Adam Smith: novas abordagens. Síntese - revista de filosofia, v. 32: 181-202, 2005.

CERQUEIRA, Hugo. A dam Smith e seu contexto: o Iluminismo escocês. Economia e sociedade, v. 26: 1-28, 2006.

CERQUEIRA, Hugo. A mão invisível de Júpiter e o método newtoniano de Smith. Estudos econômicos, v. 36: 667-697, 2006b.

DOMINGUES, Ivan. 0 grau zero do conhecimento: o problema da fundamentação das ciências humanas. São Paulo: Loyola, 1991.

EVENSKY, Jerry. The evolution of Adam Smith's views on political economy, History of political economy, v. 21(1): 123-45, 1989.

EVENSKY, Jerry. Ethics and the invisible hand, Journal of economic perspectives, V. 7(2): 197-205, 1993.

FERGUSON, Adam. A n essay on the history of civil society. Cambridge: Cambridge Univ. Press, 1995 [1767].

FLEISCHACKER, Samuel. On A dam Smith's 'Wealth of nations': a philosophical companion. Princeton: Princeton University Press, 2004.

HAAKONSSEN, Knud. The science of a legislator: the natural jurisprudence of David Hume and Adam Smith. Cambridge: Cambridge University Press, 1981.

HAAKONSSEN, Knud. Introduction. In: SMITH, Adam. The theory of moral sentiments. Cambridge: Cambridge University Press, 2002.

HAAKONSSEN, Knud. Natural jurisprudence and the theory of justice. In: BROADIE, Alexander (ed.). The Cambridge companion to the Scottish Enlightenment. Cambridge: Cambridge University Press, 2003, pp. 205-221.

HOBBES, Thomas. Leviathan. Ed. Richard Tuck. Cambridge: Cambridge University Press, 1996 [1651].

HUME, David. Tratado da natureza humana. Tradução de Déborah Danowski. São

Paulo: Ed. Unesp / Imprensa Oficial, 2001. 
HUME, David. A treatise of human nature. Ed. L. A. Selby-Bigge, revista por P. Nidditch. Oxford: Clarendon Press, 1978 [1739-40].

HUME, David. A kind of history of my life. In: NORTON, David Fate (ed.). The Cambridge companion to H ume. Cambridge: Cambridge University Press, 1993 [1734].

HUME, David. Political essays. Cambridge: Cambridge Univ. Press, 1994.

HUME, David. An enquiry concerning the principles of morals. Oxford: Oxford University Press, 2003 [1751].

HUTCHESON, Francis. An inquiry into the original of our ideas of beauty and virtue. Ed. Wolfgang Leidhold. Indianapolis: Liberty Fund, 2004 [1725].

HUTCHESON, Francis. A short introduction to moral philosophy in three books; containing the elements of ethics and the law of nature. Hildesheim: George Olms Verlag, 1990 [1747].

KAYE, F. B.. Introduction. In: MANDEVILLE, Bernard. The Fable of the Bees, or Private Vices, Publick Benefits, Indianapolis: Liberty Fund, 1988 [1924].

KLEER, Richard. Final causes in Adam Smith's Theory of moral sentiments. Journal of the history of philosophy, v. 33(2): 275-300, 1995.

MACFIE, A. L.. The individual in society: papers on Adam Smith. London: George Allen \& Unwin, 1967.

MACLAURIN, Colin. A general view of Sir Isaac Newton's method, and of his account of the system of the world. In: BROADIE, Alexander (ed.). The Scottish enlightenment: an anthology. Edinburgh: Canongate, 1997.

MANDEVILLE, Bernard. The Fable of the Bees, or Private Vices, Publick Benefits, Indianapolis: Liberty Fund, 1988 [1729].

MULLER, Jerry Z.. A dam Smith in his time and ours: designing the decent society, Princeton: Princeton University Press, 1995 [1993].

NEWTON, Isaac. Opticks: or, a treatise of the reflections, refractions, inflexions and colours of light. London: W. and J. Innnis, 1718. [Reprodução em fac-símile da 2a edição com acréscimos, disponível em http:/ / burndy.mit.edu/ Collections/ Babson/ Online/ ].

NORTON, David Fate. Hume, human nature, and the foundations of morality. In: (ed.). The Cambridge companion to Hume. Cambridge: Cambridge University Press, 1993.

OTTESON, James R.. A dam Smith's marketplace of life. Cambridge: Cambridge University Press, 2002.

RAPHAEL, D. D.. The impartial spectator. In: SKINNER, Andrew; WILSON, Thomas. Essays on Adam Smith. Oxford: Clarendon Press, 1975.

SHAFTESBURY, Anthony Ashley Cooper, Conde de. Characteristics of men, manners, opinions, times. Ed. Lawrence Klein. Cambridge: Cambridge University Press, 2001 [1711].

SMITH, Adam. The theory of moral sentiments. Eds. D. D. Raphael e A. L. Macfie. Indianapolis: Liberty Fund, 1982 [1759]. 
SMITH, Adam. Lectures on rhetoric and belles lettres. Ed. J. C. Bryce. Indianapolis: Liberty Fund, 1985 [1963].

SMITH, Adam. An inquiry into the nature and causes of the wealth of nations. Eds. R. H. Campbell, A. S. Skinner e W. B. Todd. Indianapolis: Liberty Fund, 1981 [1776].

SMITH, Adam. Correspondence of Adam Smith. Eds. E. C. Mossner e I. S. Ross. Indianapolis: Liberty Fund, 1987.

SMITH, Adam. Essays on philosophical subjects. Ed. W. P. D. Wightman. Indianapolis: Liberty Fund, 1982 [1795].

TURCO, Luigi. Moral sense and the foundations of morals. In: BROADIE, Alexander (ed.). The Cambridge companion to the Scottish Enlightenment. Cambridge: Cambridge University Press, 2003, pp. 136-156.

TURNBULL, George. Observations upon liberal education, in all its branches. Ed. Terrence O. Moore, Jr., Indianapolis: Liberty Fund, 2003.

VINER, Jacob. Adam Smith and laissez faire. In: CLARK, John M. et alli. Adam Smith 1776-1726: lectures to commemorate the sesquicentennial of the publication of 'The wealth of nations'. New York: Augustus M. Kelley, 1966 [1928].

WOOD, Paul. Science and the pursuit of virtue in the A berdeen enlightenment. In: STEWART, M. A. (ed.). Studies in the philosophy of the Scottish Enlightenment. Oxford: Clarendon Press, 2000, pp. 126-149.

WOOD, Paul. Science in the Scottish Enlightenment. In: BROADIE, Alexander (ed.). The Cambridge companion to the Scottish Enlightenment. Cambridge: Cambridge University Press, 2003, pp. 94-116.

Endereço do Autor:

Av. Antônio Carlos, 6627

Cedeplar-FACE-UFMG

31270-901 Belo Horizonte - MG 